\title{
Corrigendum
}

\section{THE IMPORTANCE OF TIME OF SPRAYING, DESICCANT TYPE AND HARVEST TIME ON INDUSTRIAL FIBRE PRODUCTION FROM STAND-RETTED FIBRE FLAX (LINUM USITATISSIMUM)}

Please note the authorship and author affiliations of the above article, originally published online on 23 March 2007 (doi: 10.1017/S0021859607007010) and appearing in print in volume 145 (6), have changed and should read as follows:

\section{S. J. BENNETT ${ }^{1 *}$, D. WRIGHT ${ }^{2}$, R. SNELL ${ }^{1}$, K. L. BRAYSON ${ }^{1}$, L. JOHNSON $^{1}$, J. P. R. E. DIMMOCK ${ }^{1}$ AND G. EDWARDS-JONES ${ }^{2}$ \\ ${ }^{1}$ Henfaes Research Centre, School of Agricultural and Forest Sciences, University of Wales Bangor, Abergwyngregyn, Llanfairfechan, Gwynedd LL33 OLB, UK \\ ${ }^{2}$ School of Agricultural and Forest Sciences, University of Wales Bangor, Deiniol Rd, Bangor, Gwynedd LL57 2UW, UK}

Furthermore, the acknowledgements section should now read:

We would like to thank the European Union, The National Assembly for Wales Agricultural Department and the Welsh Development Agency for funding this work. Thanks also to Mark Hughes and Tony John for technical help. 